\title{
Dimensional Alterations and Solubility of New Endodontic Sealers
}

\author{
Patrícia Campos Ferreira ROSA ${ }^{1}$ \\ Maria Nadir Gasparoto MANCINI ${ }^{2}$ \\ Samira Esteves Afonso CAMARGO ${ }^{1}$ \\ Angela Delfina Bittencourt GARRIDO ${ }^{3}$ \\ Carlos Henrique Ribeiro CAMARGO ${ }^{4}$ \\ Sigmar de Mello RODE 5
}

\author{
${ }^{1}$ Dental School, São Paulo State University, São José dos Campos, SP, Brazil \\ ${ }^{2}$ Department of Biochemistry, São Paulo State University, São José dos Campos, SP, Brazil \\ ${ }^{3}$ Dental School, University of Ribeirão Preto, Ribeirão Preto, SP, Brazil \\ ${ }^{4}$ Department of Endodontics, São Paulo State University, São José dos Campos, SP, Brazil \\ ${ }^{5}$ Department of Dental Materials, São Paulo State University, São José dos Campos, SP, Brazil
}

\begin{abstract}
This study evaluated the dimensional alterations and the solubility of two experimental endodontic sealers based on Copaifera multijuga oil-resin (Biosealer) and castor oil bean cement (Poliquil), maintained in different storage solutions. Twenty specimens ( $3 \mathrm{~mm}$ diameter and $2 \mathrm{~mm}$ height) of each sealer were assigned to 2 groups $(\mathrm{n}=10)$ according to the storage solution: simulated tissue fluid (STF) or distilled water (DW). The specimens were stored in these solutions during 90 days, being removed every 30 days for weighting. The solutions were renewed every 15 days. The results were subjected to statistical analysis by Dunn's and Mann-Whitney tests $(\alpha=0.05)$. The solubility of Poliquil was higher in STF $(38.4 \pm 36.0)$ than in DW $(28.4 \pm 15.0)$, while Biosealer showed higher solubility in DW $(34.61 \pm 6.0)$ than in STF $(18.59 \pm 8.0)$. The storage solution influenced the behavior of sealers in relation to the weight variation $(\mathrm{p}=0.0001)$. Poliquil presented higher variation of weight independent of the solution $(\mathrm{p}=0.239)$. Biosealer also presented higher variation of weight regardless of the solution $(\mathrm{p}=0.0001)$. The solubility of Biosealer was different from that of Poliquil, but both sealers showed low solubility in STF. Under the tested conditions, neither of the materials were according to the ADA'S specification.
\end{abstract}

Key Words: endodontic sealers, root canal filling, endodontic.

\section{INTRODUCTION}

The dimensional stability of an endodontic sealer is important to provide the hermetic seal of root canal system to avoid the bacterial proliferation and increase the success of the endodontic treatment (1-3).

Phytotherapics have shown satisfactory results in several health fields, sometimes substituting the allopathic drugs. In Dentistry, phytotherapy research applied to endodontics has been explored to find less aggressive and biocompatible products with accessible cost (4).

Recently, a material based on a polymer derived from the castor oil plant (Ricinus communis) was introduced to Endodontics $(4,5)$. The castor bean polyurethane cement (Poliquil; Poliquil Araraquara Polimeros Químicos Ltda., Araraquara, SP, Brazil) is composed of $81 \%$ to $96 \%$ triglyceride of ricinoleic acid, and is considered a natural polyol containing 3 hydroxyl radicals. This material has been reported to have antibacterial properties, is compatible with living connective tissues, has the potential to facilitate tissue healing, shows good mechanical properties, and is available at low cost (4). It has been successfully used as a retrograde filling material in apical surgeries, and as a sealer for root canal fillings $(5,6)$.

The Copaifera multijuga oil-resin has been shown to have antiinflammatory, gastric protection,

Correspondence: Profa. Dra. Patrícia Campos Ferreira da Rosa, Faculdade de Odontologia de São José dos Campos, UNESP, Alameda Salgo, 149 , residencial 11, Alphaville, 06540-420 Santana de Parnaíba, SP, Brasil. Tel: +55-11-4153-7997. Fax: +55-11-4195-6582. e-mail: patycfr@gmail.com 
analgesic, wound healing $(7,8)$, anti-nociceptive (9), and antimicrobial $(10,11)$ properties. The possibility of a setting reaction between the alkaline constituents of calcium hydroxide and zinc oxide and the Copaifera multijuga oil-resin stimulated the search for biotechnological advances, aiming to obtain a new product based on the application of phytotherapy in endodontics. A new sealer (Biosealer, São Paulo, SP, Brazil) has been developed with a powder and a liquid component that are mixed to obtain the final product (12). The powder is composed of zinc oxide, calcium hydroxide, bismuth subcarbonate, natural resin (rosin) and borax, and the liquid is purified Copaifera multijuga oil-resin (12).

However, it is important to evaluate the characteristics of this sealer as any new dental product must be tested before being cleared for clinical use (8). According to Garrido et al. (12), Biosealer stimulates the repair and wound healing, does not promote tissue irritation, and presents antibacterial and antiinflammatory activity. In addition, it fulfils the chemical and physics requirements of the American Dental Association (ADA), as for satisfactory setting time, solubility, dimensional stability, flowing and radiopacity. This sealer also costs 3-fold less than Endofill (Dentsply Ind. e Com. Ltda., Petrópolis, RJ, Brazil), 4-fold less than Sealer 26 (Dentsply Ind. e Com. Ltda.), and 6-fold less AH Plus (Dentsply De Trey GmbH, Konstanz, Germany) promoting a wide use in clinical practice (12).

The aim of this study was to evaluate the dimensional stability and solubility of two experimental root canal sealers based on Copaifera multijuga oil-resin (Biosealer) and castor oil bean (Poliquil) after storage in distilled water (DW) or simulated tissue fluid (STF).

\section{MATERIAL AND METHODS}

Biosealer was prepared at a ratio of $0.43 \mathrm{~g}$ of powder and $0.2 \mathrm{~mL}$ of liquid according to Garrido et al. (12) and Poliquil was prepared using a powder-toliquid mixing ratio according to the manufacturer's specifications.

Twenty specimens of each material were performed in matrix of Aquasil Ultra (Dentsply, Ind. e Com. Ltda.) with $3 \mathrm{~mm}$ of diameter and $2 \mathrm{~mm}$ of depth. The specimens were divided in 2 groups containing 10 specimens in each group according to the storage medium (DW or STF). The specimens were kept at conditions of $95 \%$ humidity and $37^{\circ} \mathrm{C}$ for 15 days. After the setting time, the surfaces of the specimens were polished with 600-grit sandpapers and then removed from the matrix and the initial weighting was performed in a digital balance (Eletronic Balance Bioprecisa; FA 2104 N, Shanghai, China).

The specimens were immersed again in $2 \mathrm{~mL}$ of DW or in $2 \mathrm{~mL}$ of STF (prepared by the Laboratory of Biochemistry of the São José dos Campos Dental School, São Paulo Sate University, Brazil) based on bloody plasma of rabbit diluted in sterile water, in the proportion 1:5, supplemented with glucose ( $85 \mathrm{mg} \%)$.

The specimens were kept in clean sterile glass flasks for 90 days. Every 30 days the specimens were removed of the storage medium, the excess of the liquid was dried with an absorbent tissue, and they were reweighed with the same digital balance.

The values of dimensional alterations in percentile were calculated based on the rules of ADA (13), using the following equation:

$$
\frac{P_{y}-P_{i}}{P_{i}} \times 100
$$

$\mathrm{P}_{i}$ - initial weight of the specimen; $\mathrm{P}_{\mathrm{y}}$ - weight of the specimen each 30 days.

The solubility data were analyzed statistically by Tukey's and Kruskal-Wallis tests at 5\% significance level.

\section{RESULTS}

After 30, 60 and 90 days of immersion in the storage solutions, the percentage values of final weight were compared to the initial weight values (Table 1). After 90 days in DW, Biosealer increased the weight by

Table 1. Percent weight variation of Biosealer and Poliquil after 30, 60 and 90 days in the different storage medium.

\begin{tabular}{lcccc}
\hline \multirow{2}{*}{$\begin{array}{l}\text { Endodontic } \\
\text { sealers }\end{array}$} & $\begin{array}{c}\text { Storage } \\
\text { medium }\end{array}$ & & \multicolumn{3}{c}{ Period } \\
\cline { 4 - 5 } Biosealer & DW & $26.50 \%$ & $35.03 \%$ & $34.61 \%$ \\
& STF & $20.24 \%$ & $24.00 \%$ & $18.59 \%$ \\
Poliquil & DW & $32.70 \%$ & $43.50 \%$ & $28.40 \%$ \\
& STF & $35.00 \%$ & $48.80 \%$ & $38.40 \%$ \\
\hline
\end{tabular}


$34.6 \%$ compared to initial weight. In contrast, weight increased by $18.6 \%$ after the same immersion period in STF, showing difference statistically significant between the storage medium $(\mathrm{p}=0.000)$.

Poliquil presented greater weight alteration in STF compared to DW after 90 days of storage $(\mathrm{p}=0.239)$. Biosealer presented significantly lesser weight variation than Poliquil after 90 days in STF $(\mathrm{p}=0.000)$ (Table 1 and Fig. 1).

\section{DISCUSSION}

Dimensional alterations might occur in endodontic sealers as a contraction of their volume, which can create empty spaces between dentin and filling promoting a possible bacterial contamination in that area. In contrast, the high expansion of volume can cause some inconveniences as the adhesion fails between the endodontic sealer and dentin $(14,15)$. According to the ADA, solubility and disintegration of an endodontic sealer should not exceed $3 \%$ of the initial volume $(12,16,17)$.

In the present study, the solubility of an endodontic sealer was evaluated by weight variation of specimens considering that the weight variation is higher as much as the expansion that the endodontic sealer suffers in the storage medium. Thus, after 90 days, the of Biosealer specimens increased by $35 \%$ and $18.6 \%$ in DW and STF, respectively, which is above the ADA'S recommendation. Poliquil also showed a volume increase by $28.4 \%$ and $38.4 \%$ in DW and STF, respectively. According some studies, the most of endodontic sealers present an initial expansion and disintegration with the time (16-19).

In contrast, Garrido et al. (12) investigated the chemical and physical properties of Biosealer and verified that this sealer lost its weight by $0.96 \%$ compared to the initial weight. However, the authors reported that Biosealer presented satisfactory results for all chemical physical tests, being considered as a good endodontic sealer.

In the present study, Biosealer showed expansion values in both storage media, probably due to the presence of rosin (natural resin) in its formulation (22\%). The presence of rosin in a sealer plays an important role in its expansion (12).

In the present study, Poliquil presented high expansion values, which can be attributed to the hygroscopic property due to calcium carbonate and zinc oxide in its formulation (20). Both phytotherapic endodontic sealers showed a good potential as a new option for filling of root canal procedures. However, Biosealer and Poliquil should be further investigated before its use in clinical situations can be recommended.

The solubility of Biosealer was different from that of Poliquil, but both sealers showed low solubility in STF. Under the tested conditions, neither of the materials were according to the ADA'S specification.

\section{RESUMO}

O presente estudo avaliou a alteração dimensional e solubilidade de 2 cimentos experimentais (à base de resina do óleo de Copaíba Biosealer e cimento do polímero da mamona - Poliquil), mantidos em diferentes meios de armazenamento. Foram confeccionados 20 espécimes de cada cimento com $3 \mathrm{~mm}$ de diâmetro e $2 \mathrm{~mm}$ de altura os quais foram divididos em 2 grupos $(n=10)$ de acordo

A
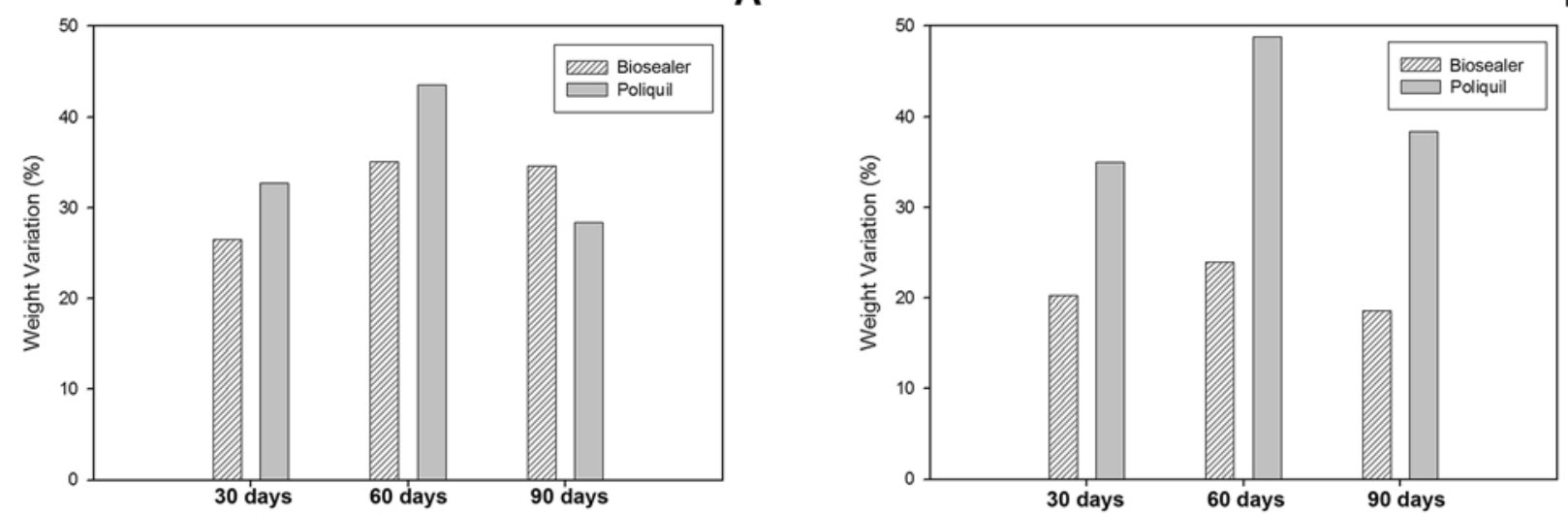

Figure 1. Comparison of weight variation of the sealers after storage in distilled water (A) and simulated tissue fluid (B). 
com o meio de armazenamento (fluido tissular simulado ou água destilada). Os espécimes foram atidos nas soluções durante 90 dias, sendo removidos a cada 30 dias para pesagem das amostras, no entanto as soluções foram trocadas a cada 15 dias. Os resultados foram submetidos aos testes de Dunn (5\%) e Mann-Whitney. Os meios de armazenamento causaram influência no comportamento dos cimentos em relação ao peso $(p=0,0001)$. Poliquil apresentou alta variação de peso independente da solução $(p=0,239)$. Biosealer também apresentou alta variação de peso independente da solução $(\mathrm{p}=0,0001)$. A solubilidade do Biosealer foi diferente do Poliquil, entretanto, ambos cimentos mostraram baixa solubilidade no fluido tissular simulado. Nas condições do experimento, nenhum cimento está de acordo com a especificação da ADA.

\section{ACKNOWLEDGEMENTS}

The authors gratefully acknowledge Prof. Manoel Damião de Sousa-Neto for providing the Copaifera multijuga oil-resin (Biosealer) used in this study.

\section{REFERENCES}

1. Caicedo R, von Fraunhofer JA. The properties of endodontic sealer cements. J Endod 1988;14:527-534.

2. Orstavik D, Nordahl I, Tibballs JE. Dimensional change following setting of root canal sealer materials. Dent Mater 2001;17:512519.

3. Sousa-Neto MD, Guimarães LF, Saquy PC, Pécora JD. Effect of different grades of gum rosins and hydrogenated resins on the solubility, disintegration, and dimensional alterations of Grossman cement. J Endod 1999;25:477-480.

4. Barros VMR, Rosa AL, Beloti MM, Chierice G. In vivo biocompatibility of three different chemical compositions of Ricinus communis polyurethane. J Biomed Mat Res Part A 2003;67:235-239.

5. Pascon EA, Sousa CJA, Langeland K. Biocompatibility of endodontic materials: cytotoxicity of a polyurethane resin derived from castor bean oil. Braz Endod J 2001;5:5-12.

6. Souza EM, Wu M-K, Shemesh H, Bonetti-Filho I, Wesselink PR. Comparability of results from two leakage models. Oral Surg Oral Med Oral Pathol Oral Radiol Endod 2008;106:309-313.

7. Carvalho JCT, Cascon V, Possebon LS, Morimoto MS, Cardoso LG, Kaplan MA et al.. Topical antiinflammatory and analgesic activities of Copaifera duckei Dwyer. Phyto Res 2005;19:946-950.
8. Veiga-Junior VF, Rosas EC, Carvalho MV, Henriques MGMO, Pinto AC. Chemical composition and anti-inflammatory activity of copaiba oils from Copaifera cearensis Huber ex Ducke, Copaifera reticulata Ducke and Copaifera multijuga Hayne - A comparative study. J Ethnoph 2007;112:248-254.

9. Gomes NM, Rezende CM, Fontes SP, Matheus ME, Fernandes PD. Antinociceptive activity of Amazonian copaiba oils. J Ethnoph 2007;12:486-492.

10. Costa-Lotufo LV, Cunha GM, Farias PA, Viana GS, Cunha KM, Pessoa C, et al.. The cytotoxic and embryotoxic effects of kaurenoic acid, a diterpene isolated from Copaifera langsdorffii oleo-resin. Toxicon 2002;40:1231-1234.

11. Santos AO, Nakamura-Ueda T, Dias Filho BP, Veiga-Junior VF, Pinto AC, Nakamura CV. Antimicrobial activity of Brazilian copaíba oils obtained from different species of the Copaifera genus. Mem Instit Oswaldo Cruz 2008;103:277-281.

12. Garrido AD, Lia RC, França SC, da Silva JF, Astolfi-Filho S, Sousa-Neto MD. Laboratory evaluation of the physicochemical properties of a new root canal sealer based on Copaifera multijuga oil-resin. Int Endod J 2010;43:283-291.

13. American National Standards Institute/American Dental Association. Specification $\mathrm{n}^{\circ} 57$ for endodontic filling materials. JADA 1984;108:88.

14. Kazemi RB, Safavi KE, Spångberg LS. Dimensional changes of endodontic sealers. Oral Surg Oral Med Oral Pathol 1993;76:766771.

15. Driscoll CF, Woolsey GD, Reddy TG, Craig RG. Solubility of oxide-eugenol and calcium hydroxide cements in simulated dentinal fluid. J Oral Rehabil 1989;16:451-455.

16. Carvalho-Junior JR, Guimarães LFL, Correr-Sobrino L, Pécora JD, Sousa-Neto MD. Evaluation of solubility, disintegration, and dimensional alterations of a glass ionomer root canal sealer. J Braz Dent 2003;14:114-118.

17. Hosoya N, Kurayama H, Iino F, Arai T. Effects of calcium hydroxide on physical and sealing properties of canal sealers. Int Endod J 2004;37:178-188.

18. Jayalatha NS, Kuriakose S, Saradadevi KL. Comparison of sealing ability of three different root canal sealers - an in vitro study. J Indian Soc Pedod Prev Dent 1998;16:122-126.

19. Tagger M, Tagger E, Tjan AH, Bakland LK. Measurement of adhesion of endodontic sealers to dentin. J Endod 2002;28:351354.

20. Pinheiro CR, Guinesi AS, Pizzolitto AC, Bonetti-Filho I. In vitro antimicrobial activity of Acroseal, Polifil and Epiphany against Enterococcus faecalis. Braz Dent J 2009;20:107-111.

Accepted September 9, 2010 